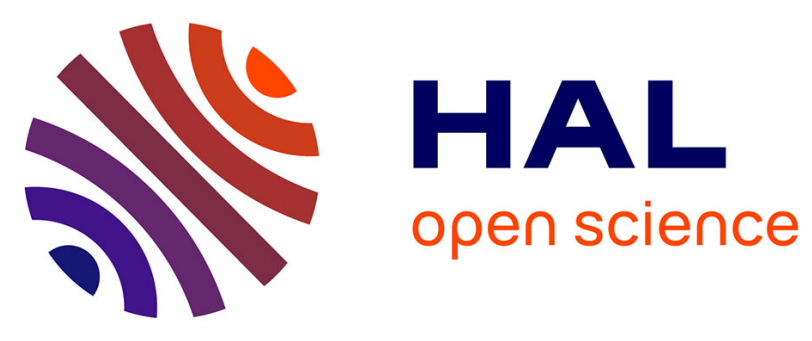

\title{
Lipo-Protein Emulsion Structure in the Diet Affects Protein Digestion Kinetics, Intestinal Mucosa Parameters and Microbiota Composition
}

Marion M. Oberli, Véronique Douard, Martin Beaumont, Daphné Jaoui, Fabienne Devime, Sandy Laurent, Catherine Chaumontet, Damien Mat, Steven Le Feunteun, Camille Michon, et al.

\section{To cite this version:}

Marion M. Oberli, Véronique Douard, Martin Beaumont, Daphné Jaoui, Fabienne Devime, et al.. Lipo-Protein Emulsion Structure in the Diet Affects Protein Digestion Kinetics, Intestinal Mucosa Parameters and Microbiota Composition. Molecular Nutrition and Food Research, 2018, 62 (2), pp.1700570. 10.1002/mnfr.201700570 . hal-01619023

\section{HAL Id: hal-01619023}

https://hal-agroparistech.archives-ouvertes.fr/hal-01619023

Submitted on 26 May 2020

HAL is a multi-disciplinary open access archive for the deposit and dissemination of scientific research documents, whether they are published or not. The documents may come from teaching and research institutions in France or abroad, or from public or private research centers.
L'archive ouverte pluridisciplinaire HAL, est destinée au dépôt et à la diffusion de documents scientifiques de niveau recherche, publiés ou non, émanant des établissements d'enseignement et de recherche français ou étrangers, des laboratoires publics ou privés. 


\title{
LIPO-PROTEIN EMULSION STRUCTURE IN THE DIET AFFECTS PROTEIN DIGESTION KINETICS, INTESTINAL MUCOSA PARAMETERS AND MICROBIOTA COMPOSITION
}

\author{
Marion Oberli $^{1 *}$, Véronique Douard ${ }^{2 * \#}$, Martin Beaumont ${ }^{1}$, Daphné Jaoui ${ }^{2}$, Fabienne \\ Devime $^{2}$, Sandy Laurent ${ }^{1}$, Catherine Chaumontet ${ }^{1}$, Damien Mat $^{3}$, Steven Le Feunteun ${ }^{3}$, \\ Camille Michon ${ }^{4}$, Anne-Marie Davila ${ }^{1}$, Gilles Fromentin ${ }^{1}$, Daniel Tomé ${ }^{1}$, Isabelle Souchon ${ }^{3}$, \\ Marion Leclerc ${ }^{2}$, Claire Gaudichon ${ }^{1 \#}$, François Blachier ${ }^{1}$
}

${ }^{1}$ Micalis Institute, INRA, AgroParisTech, Université Paris-Saclay, 78350 Jouy-en-Josas, France

${ }^{2}$ UMR PNCA, AgroParisTech, INRA, Université Paris-Saclay, 75005, Paris, France

${ }^{3}$ UMR GMPA, AgroParisTech, INRA, Université Paris-Saclay, 78850, Thiverval-Grignon, France

${ }^{4}$ UMR GENIAL, AgroParisTech, INRA, Université Paris-Saclay, 91300, Massy, France

*: these authors contributed equally to the work
\# co-corresponding authors: Claire Gaudichon : claire.gaudichon@agroparistech.fr ; Véronique

Douard : veronique.douard@inra.fr

\section{Key words}

Digestion, food structure, gut peptides, gut microbiota, stomach emptying, dietary protein

Received: 05/07/2017; Revised: 04/09/2017; Accepted: 27/09/2017

This article has been accepted for publication and undergone full peer review but has not been through the copyediting, typesetting, pagination and proofreading process, which may lead to differences between this version and the Version of Record. Please cite this article as doi: 10.1002/mnfr.201700570.

This article is protected by copyright. All rights reserved. 


\section{Abbreviations}

AA: amino acid ; APE: atom percent excess ; CKK: cholecystokinin ; GCE: gelled coarse emulsion ; GI: gastro-intestinal ; GIP: gastric inhibitory peptide ; GLP-1: glucagon-like peptide-1 ; LFE: liquid fine emulsion ; N: nitrogen ; NEFA: non esterified fatty acids ; OTU: operating taxonomy unit ; PYY: peptide YY ; ROD: real whey protein oro-cecal digestibility ; TG: triglyceride ; peptide YY ; SCFA: short chain fatty acids.

\section{ABSTRACT}

\section{Scope}

Food structure is a key factor controlling digestion and nutrient absorption. We tested the hypothesis that protein emulsion structure in the diet may affect digestive and absorptive processes.

\section{Methods \& results}

Rats $(n=40)$ were fed for 3 weeks two diets chemically identical but based on lipid-protein liquid-fine (LFE) or gelled-coarse (GCE) emulsions that differ at the macro- and microstructure levels. After an overnight fasting, they ingested a ${ }^{15} \mathrm{~N}$-labeled LFE or GCE test meal and were euthanized $0,15 \mathrm{~min}, 1 \mathrm{~h}$ and $5 \mathrm{~h}$ later. ${ }^{15} \mathrm{~N}$ enrichment in intestinal contents and ${ }^{15} \mathrm{~N}$ blood fate were measured. Gastric emptying, protein digestion kinetics, ${ }^{15} \mathrm{~N}$ absorption and incorporation in blood protein and urea were faster with LFE than GCE. At 15min timepoint, LFE group showed higher increase in GIP portal levels than GCE. Three weeks of dietary adaptation led to higher expression of cationic amino acid-transporters in ileum of LFE compared to GCE. LFE diet raised cecal butyrate and isovalerate proportion relative to GCE, suggesting increased protein fermentation. LFE diet increased fecal Parabacteroides relative abundance but decreased Bifidobacterium, Sutterella, Parasutterella genera, and Clostridium cluster XIV abundance.

This article is protected by copyright. All rights reserved. 


\section{Conclusion}

Protein emulsion structure regulates digestion kinetics and gastrointestinal physiology, and could be targeted to improve food health value.

Food processing alters food structure raising the question how that affects its digestion. To investigate this we created two chemically identical diets which differed in macro- and microstructure of protein-lipid emulsion. We found that these structural differences in lipo-protein matrix incorporated in the diet had major effects on dietary protein digestion kinetics, nitrogenous compound absorption and incorporation in blood protein. This was associated with changes in endocrine response of the proximal intestine and modification and activity of the gut microbiota.
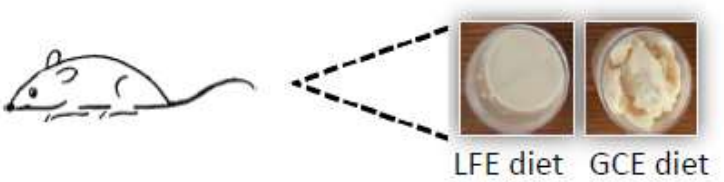

\section{$\underline{\text { LFE vs GCE impacts in the gastrointestinal tract }}$}

Stomach:

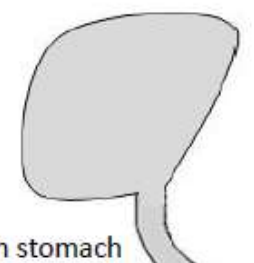

\section{Cecum}

$\bullet \leftrightarrow$ dietary $\mathrm{N}$ in small intestine content after $15 \mathrm{~min}$, $1 \mathrm{~h}$ and $5 \mathrm{~h}$

- $\downarrow$ dietary $\mathrm{N}$ in stomach content after $15 \mathrm{~min}$ and $1 \mathrm{~h}$ $\bullet \leftrightarrow$ dietary $\mathrm{N}$ in content after $5 \mathrm{~h}$

- $\leftrightarrow$ gastric content after

$15 \mathrm{~min}$ and $1 \mathrm{~h}$

- $\uparrow$ butyrate and isovalerate after 3 wks intestine content after $15 \mathrm{~min}$, $1 \mathrm{~h}$ and $5 \mathrm{~h}$

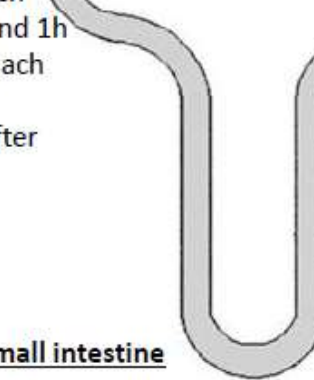

- $\leftrightarrow$ dietary $\mathrm{N}$ in small intestine content after $15 \mathrm{~min}$ and $1 \mathrm{~h}$

- $\downarrow$ dietary $\mathrm{N}$ in small intestine content after $5 \mathrm{~h}$
- $\uparrow$ Parabacteroides after 3 wks - $\downarrow$ Bifidobacterium, Sutterella, Parasutterella genera, and Clostridium cluster XIV after 3 wks 


\section{INTRODUCTION}

Pre-processed or ultra-processed food has become a prominent part of the diet in western countries [1, 2]. This rise in their consumption may partly account for the increased prevalence of a number of metabolic diseases [3, 4]. Observational nutritional studies have shown that the impact of diet on health parameters cannot be explained only by the chemical composition itself, but that the food structure, which can be substantially altered by food processing, should also be taken into account $[5,6]$. Along with other food constituents, the functional properties of proteins in food matrixes can be drastically modified by the processing methods [7, 8]. The emulsifying properties of the proteins are particularly sensitive to thermal treatments, which reduce protein emulsion droplet size and may affect their digestibility [9]. Other (food) processing procedures currently used in human and animal food industry such as freezing, extrusion or high pressure treatment also alter the emulsion properties of proteins [7], thereby potentially affecting food digestion and nutrient absorption.

In addition, according to different protein sources, heat treatments and gelation may influence the micro- and macrostructure of food matrices, and consequently, dietary protein digestion and absorption [10, 11]. In humans, different dietary nitrogen $(\mathrm{N})$ sources can display different coagulation properties in the stomach acidic environment. For instance, casein is retained longer in the stomach than the whey proteins [12] [13], impacting the speed of amino acid (AA) absorption in the gut and affecting the whole body protein anabolism [14]. When compared to milk, dairy product gel structure delays gastric emptying rate and subsequently decreases the kinetics of AA absorption in minipig [15]. Similarly, the way milk coagulates (acidification versus renneting) affects the AA digestion, release and apparent bioavailability in the same animal model [10]. In humans, a semi solid meal decreases the gastric emptying rates and improves satiety feeling, when compared to liquid meal of similar composition, This article is protected by copyright. All rights reserved. 
despite a lower release of cholecystokinin (CCK) [16]. Thus, by regulating gut emptying rate and digestion kinetics, the physical properties of protein food matrix significantly affect AA and peptide absorption kinetics and may thus impact gut hormone signaling, although the link remains inconsistent in human studies $[13,17,18]$. The quantity and quality of undigested food reaching the distal part of the gastro-intestinal (GI) tract (ileum and large intestine) may also affect the colonic microbial ecosystem composition and its fermentation activities [19] as well as the amount of metabolites produced by the intestinal microbiota from undigestible or not fully digested substrates [20] [21] [22].

We generated two lipo-protein emulsions of identical chemical composition, namely a liquid fine emulsion (LFE) and a gelled coarse emulsion (GCE), that display very different microstructure (ratio of fat globule diameter GCE / LFE $=26.5$ ) and macrostructure (liquid or gelified) characteristics [23]. We showed in vitro that LFE displays higher initial rate of both proteolysis and lipolysis than GCE [23]. In a previous in vivo study, we showed that when incorporated into the diet, the LFE up-regulates (relative to GCE) selective expression of AA transporter systems in the ileum, increases the Lactobacillus abundance and enhances the caecal concentration of isovalerate, a leucine-derived short chain fatty acids (SCFA) [24]. Here, we aimed to test, in vivo, the impact of the lipo-protein emulsion structure in the diet on the dietary protein digestion kinetics and on the AA incorporation in $\mathrm{N}$ metabolic pools. This was performed by measuring protein digestibility using ${ }^{15} \mathrm{~N}$-labeled protein in the diet and by tracing the ${ }^{15} \mathrm{~N}$ fate in the gastrointestinal tract, and in the amino acids, proteins and urea in peripheral blood. The impact of the lipo-protein emulsion structure was also assessed on amino acid transporters expression in the ileum, portal concentration of entero-endocrine hormones, bacterial metabolite composition in the caecum content and on fecal microbial ecosystem. 


\section{MATERIALS AND METHODS}

\section{Lipo-protein emulsion and diet preparation}

Two food matrices displaying identical macro- and micro-nutriment composition (10 wt \% rapeseed oil, Lessieur, France and 15 wt \% whey proteins isolate, Prolacta 80, Lactalis, France) but with different lipo-proteinemulsion structures at the macroscopic and microscopic scales were prepared as described previously [23]. The LFE displayed oil droplets of $\sim 0.75 \mu \mathrm{m}$ and the GCE displayed oil droplet of $\sim 19.5 \mu \mathrm{m}$. The GCE samples were chopped with a kitchen food grinder (Braun Turbo $600 \mathrm{~W}$ type 4191) during $3 \mathrm{~s}$ to produce pieces in the 3 to $5 \mathrm{~mm}$ range. Both matrices were then frozen at $-80^{\circ}$ and freezedried. Two diets, LFE and GCE, with a different lipo-protein emulsion structure were composed with all the protein and lipids contained in LFE or GCE matrices respectively, and mixed with the other diet ingredients (Table 1).

\section{Animals and experimental design}

This study was conducted in accordance with French guidelines on animal experimentation and validated by the Ethics Committee in Animal Experiment of INRA Jouy-en-Josas (Comethea, registration number: APAFIS\#4179-2016021609463495). Forty male Wistar Han rats (Envigo, Gannat, France) aged 7 weeks were individually housed and maintained in an inverted $12 \mathrm{~h}$-light/12h-dark cycle with the dark period beginning at 7:00 AM. After a 1-week adaptation to a standard rodent diet containing $14 \%$ protein, 2 groups of 20 rats were fed $a d$ libitum for 3 weeks GCE or LFE diet. Feces were sampled by manual expulsion before and after 3 weeks of experimental diet (Figure 1A), immediately frozen in dry ice and stored at $80^{\circ} \mathrm{C}$. From the beginning of the third week (Figure 1A), rats were habituated to promptly (< $15 \mathrm{~min}$ ) consume test meals $(3 \mathrm{~g}$, dry matter). For that, a test meal was given daily at the beginning of the dark phase after an overnight (light phase) fasting and the food cups was removed after 30 minutes. After 3 weeks (Figure 1B), overnight-fasted rats were fed test 
meals (3g, dry matter) which had the same composition as experimental diets but whey proteins were intrinsically labeled with ${ }^{15} \mathrm{~N}$. Rats were euthanized $15 \min (\mathrm{n}=10), 1 \mathrm{~h}(\mathrm{n}=10)$ or $5 \mathrm{~h}(\mathrm{n}=10)$ after the end of the test meal ( 5 rats in each group for each time point). Five rats from the LFE and 5 from GCE groups were fasting (not fed the test meal) when euthanized. The rats were anesthetized with pentobarbital sodium (40 mg/kg body weight ip) before collecting portal and peripheral blood into tubes containing EDTA and protease inhibitor as described before [24]. Plasma were frozen after centrifugation and stored at $-80^{\circ} \mathrm{C}$ for peptide and biochemical analysis. Gastric, intestinal, cecal and colonic contents were collected, weighed and frozen at $-20^{\circ} \mathrm{C}$ for ${ }^{15} \mathrm{~N}$ enrichment measurements. An aliquot of cecal contents to be used for SCFA analysis was immediately frozen in liquid $\mathrm{N}$ and stored at $-80^{\circ} \mathrm{C}$. Rinsed jejunum and ileum segments were sampled and stored at $-80^{\circ}$ for gene expression analysis.

\section{Protein digestibility and exogenous $\mathbf{N}$ transfer to serum $\mathbf{N}$ pools}

For protein digestibility, total $\mathrm{N}$ and ${ }^{15} \mathrm{~N}$ enrichment of intestinal contents were assessed using an isotope ratio mass spectrometer (IRMS) (Isoprime, GV Instrument, Manchester, UK) coupled with an elemental $\mathrm{N}$ analyser (Vario Micro Cube, Elementar, Lyon, France), as previously described (for details see supplementary methods) [25]. The amount of dietary N that was absorbed was calculated as the differences between ingested $\mathrm{N}$ and dietary $\mathrm{N}$ recovered in all the segments of the gastrointestinal tract.

${ }^{15} \mathrm{~N}$ enrichment in serum free amino acids and urea-derived ammonia were also measured by IRMS after protein precipitation as previously described (for details see supplementary methods) [26-28].

\section{Short chain fatty acids in caecum contents}

SCFA were extracted from cecal contents by vigorous homogenization in ultrapure water and subsequent centrifugation (14000 g, $\left.15 \mathrm{~min}, 4^{\circ} \mathrm{C}\right)$. SCFA in supernatants were then This article is protected by copyright. All rights reserved. 
derivatized and analyzed with a gas chromatograph equipped with a capillary column (30 m, $0.32 \mathrm{~mm}$ ID; RestekRtx 502.2) and fitted with a flame ionization detector [29]. SCFA concentrations were determined by external standards with reference to internal standards and SCFA were expressed as percentage of total SCFA.

\section{Plasma analysis}

Peripheral plasma was analyzed for urea, glucose, triglycerides (TG) and non-esterified fatty acids (NEFA) by AU 400 automated biochemical analyzer (Olympus, France). Additionally, using Luminex technology (Millipore, Molsheim, France), portal plasma (undiluted) were analyzed for gastric inhibitory polypeptide (GIP), glucagon-like peptide-1 (GLP-1), peptide YY (PYY)), leptin and glucagon.

\section{Intestinal mRNA extraction and gene expression analysis}

Total RNA was isolated from jejunum and ileum segments using mirVana® miRNA isolation kit (Ambion, France). Reverse transcription was performed with $2 \mu \mathrm{g}$ total RNA using High capacity cDNA Reverse Transcription kit (Applied Biosystems, Foster City, CA). RT-PCR was performed based on TaqMan gene expression assays with predesigned Taqman primers and probes for the Rat (Assays-on-Demand ${ }^{\mathrm{TM}}$, Gene Expression Products; Applied Biosystems) (Table S1). $\beta$-actin, a housekeeping gene, was used to normalize the mRNA abundance of each target gene as described previously [24].

\section{Microbiota analysis}

Sample preparation: Total microbial DNA was extracted from $\sim 150 \mathrm{mg}$ of fecal sample as previously described [24] (for details see supplementary methods). $16 \mathrm{~S}$ rDNA sequencing bioinformatics pipeline: Paired-end reads obtained from MiSeq sequencing were merged using FLASH v1.2.11 reads software (parameters: -m 20; -M 170; -x 0.25; PHRED 33) [30]. Reads with length $\geq 400$ bp were kept and checked for quality and length using sickle [31] and corrected for known sequencing error using SPAdes [32]. Reads were clustered at 97\% This article is protected by copyright. All rights reserved. 
of identity using Vsearch pipeline. Chimeric OTUs (operating taxonomic unit) were identified using UCHIME and discarded. OTU classification was performed using RDP classifier [33]. OTU sequences were aligned using ssu-align. OTUs with abundances lower than $0.005 \%$ were removed from the analysis [34]. Supplementary Table S3 summarizes sequencing results for each sample. Sequencing data were analyzed using the Phyloseq package in $\mathrm{R}[35]$.

\section{Statistical analysis}

Effect of food structure on microbiota composition was tested using linear model with the DESeq2 analysis pipeline, using Benjamini Hochberg multi-testing correction for the pvalues. Alpha-diversities (within sample microbial diversity) were verified using observed OTU numbers, Chao1 and Shannon indexes. Digestibility differences were tested using a ttest to compare the mean of the two groups at each time. Comparisons of the incorporation of dietary $\mathrm{N}$ in the studied $\mathrm{N}$ pools were analyzed using a two-way analysis of variance (structure of the emulsion and digestion time), performed with the GLM procedure of SAS. Bonferroni's posthoc tests were used for pairwise comparison (SAS 9.1, SAS Institute, Cary, NC, USA: Mixed Procedure). Differences were considered statistically significant at $P<$ 0.05. For all the other data two-way ANOVA was performed using GraphPad Prism Version 6.02 for Windows (GraphPad Software, La Jolla California).

\section{RESULTS}

Effect of the lipo-protein emulsion structure of the diet on food intake, body weight, body composition and plasma metabolite concentration

Rats fed LFE or GCE diets displayed similar growth rates and food intake levels (Figure S1). The decrease in food intake at day 30 matched the habituation of the rats for prompt test meal ingestion. Plasma levels of glucose, TG, and NEFA were similar in both LFE and GCE This article is protected by copyright. All rights reserved. 
groups, but TG and NEFA levels changed over time after the test meal (Table 2). The NEFA levels were elevated $1 \mathrm{~h}$ and $5 \mathrm{~h}$ after the test meal compared to the levels in fasting rats. The plasma concentrations of TG were higher $1 \mathrm{~h}$ after the test meal but returned to the fasting levels $5 \mathrm{~h}$ after, in both groups.

\section{Lipo-protein emulsion structure in the diet changed intestinal kinetics of dietary $\mathbf{N}$}

The amount of dietary $\mathrm{N}$ that remained in the stomach was lower for the LFE-diet fed group of animals compared to the GCE group at $15 \mathrm{~min}$ and at $1 \mathrm{~h}(\mathrm{P}<0.0001)$ (Figure 2A). In the small intestine, there was no difference at $15 \mathrm{~min}$ and $1 \mathrm{~h}$, however the amount of dietary $\mathrm{N}$ was higher for the GCE group than for the LFE group $5 \mathrm{~h}$ after the test meal $(P=0.0012)$ (Figure 2B). Dietary $\mathrm{N}$ did not reach the cecum and the colon $15 \mathrm{~min}$ and $1 \mathrm{~h}$ after test meal ingestion. At $5 \mathrm{~h}$, dietary $\mathrm{N}$ that was not absorbed in the small intestine was found in the cecum and colon, without differences between groups (Figures $2 \mathrm{C}$ and $\mathrm{D}$ ). The time course of dietary $\mathrm{N}$ absorption (Figure 3) markedly differed between both groups (time $\mathrm{x}$ emulsion, $\mathrm{P}=0.004)$. After $15 \mathrm{~min}, 74.8 \pm 5.6 \%$ of ingested $\mathrm{N}$ has already been absorbed in LFE whereas it was $42.9 \pm 3.7 \%$ in CGE $(\mathrm{P}<0.0001)$. After $1 \mathrm{~h}$, these values where $85.1 \pm 5.1$ and $52.1 \pm 2.3 \%(\mathrm{P}<0.0001)$, respectively. After $5 \mathrm{~h}, \mathrm{~N}$ absorption was similar between groups and reached an average value of $97.1 \pm 0.2 \%$. Digestibility was also similar after $5 \mathrm{~h}$ between groups, with an average real whey protein orocecal digestibility (ROD) of $98.4 \pm 0.1 \%$.

\section{Transfer of dietary $\mathbf{N}$ to serum proteins, amino acids and urea}

The transfer of dietary $\mathrm{N}$ to serum proteins, amino acids and urea at different time points after the test meal is shown in Figure 4. Significant effects of time and emulsion structure-by-time interaction were observed in these three $\mathrm{N}$ pools. The incorporation of dietary $\mathrm{N}$ into serum proteins progressively increased over the post-prandial period and was faster with the diet containing the LFE than the GCE (Figure 4A). One hour after the test meal, the amount of dietary $\mathrm{N}$ transferred to serum proteins was higher in the LFE group than in the GCE group 
$(P=0.04)$. However, after $5 \mathrm{~h}$ of digestion, the incorporation of dietary $\mathrm{N}$ was slightly lower for the LFE (3.12\%) than for the GCE group (3.99\%) $(P=0.03)$. Transfer to serum AA pool was stable from $1 \mathrm{~h}$ after the test meal in the LFE group whereas in the GCE group, it continued to increase until 5h (Figure 4B). Five hours after the test meal, the transfer of dietary $\mathrm{N}$ to serum AA pool was lower for the LFE than the GCE group $(P=0.03)$. The transfer of dietary $\mathrm{N}$ to body urea increased until $1 \mathrm{~h}$ for both groups, then slowly declined for the LFE group but remained stable for the GCE group (Figure $4 \mathrm{C}$ ). The amount of ${ }^{15} \mathrm{~N}$ was significantly higher for the LFE group than for the GCE group after $1 \mathrm{~h}(P=0.02)$, but the residual amount of dietary $\mathrm{N}$ in body urea was not different among groups after $5 \mathrm{~h}$ and represented $6 \%$ of the ingested $\mathrm{N}$. Total urea level increased overtime after the test meal. However, $5 \mathrm{~h}$ after the test meal, the urea level dropped $30 \%$ in the LFE group but was maintained in the rats fed GCE diet. The 5-h AUCs for the transfer of dietary $\mathrm{N}$ to serum proteins, amino acids and urea were identical in both groups.

\section{Amino acid and peptide transporter expression in the small intestine}

In the jejunum, none of the expression levels of AA and peptide transporters tested were affected by the protein-lipid emulsion structure of the diet (Table 3). In the ileum, the expression levels of two genes (Slc6al4 and Slc3al) encoding the cationic AA transporter systems, system $\mathrm{B}^{(0,+)}$ and $\mathrm{b}^{(0,+)}$, were higher in the LFE group than in the GCE group. A similar tendency was also observed for the expression levels of the genes encoding the system $\mathrm{X}_{\mathrm{AG}}^{-}$and the basolateral system A. Surprisingly, a strong time effect was observed in the jejunum for four transporters (Slc15a1, Slc6a19, Slc36al and Slc3a1) and in the ileum for two transporters (Slc15al and Slc6a14). The expression level of these genes was significantly reduced $5 \mathrm{~h}$ after feeding in both GCE and LFE groups. Possibly, this reduction in AA transporter expression was the return to normal levels after an adaptive response to the This article is protected by copyright. All rights reserved. 
overnight fast. Indeed, expression levels of Slc15a1, Slc6a19, Slc3a1 and Slc1a2 were upregulated by fasting (Table S2).

\section{Impact of the lipo-protein emulsion structure on the gut peptide circulation levels}

Changes in the kinetics of nutrient release from the diet could have modified their detection by the entero-endocrine cells along the gastrointestinal tract, and thus affect the release of the gut peptides. Thus, the effect of LFE and GCE diets on the circulating levels of gut peptide as well as leptin and glucacon, was determined after the test meal (Figures 5). While the fasting levels of GIP were similar in the portal plasma of LFE and GCE fed rats, GIP level was stimulated after $15 \mathrm{~min}$ in response to the test meal and returned back to the fasting levels 5 hours later. This stimulation was significantly greater under the LFE diet than GCE diet ( $\mathrm{p}=0.020$ for 15 min time point) (Figure 5A). The fasting level of GLP-1 and PYY did no vary between the 2 diets nor in response to the test meal (Figures 5B and C). Similarly the level of glucagon and leptin in the portal plasma remained unchanged as a function of the lipo-protein emulsion structure of the diet and of the feeding status (Figures 5D and E).

\section{Bacterial metabolite composition in the lumen of the caecum}

Since changes in the release of nutrients from the diet could potentially modify the substrates available for the microbiota, we evaluated the caecal SCFA composition before and $5 \mathrm{~h}$ after the test meal. The feeding status did not modify the SCFA composition (Table 4). However, the percentages of acetate and butyrate (products of bacterial metabolism of carbohydrates and AA) varied according to the lipo-protein emulsion structure of the diet. In the caecum of LFE fed rats, the proportion of acetate was lower while the percentage of butyrate increased compared to GCE fed group (Table 4). In addition, the percentage of isovalerate was approximately 3 times higher in the rats fed LFE when compared to GCE. The total proportion of SCFA specifically derived from AA (isobutyrate, isovalerate and valerate) was This article is protected by copyright. All rights reserved. 
also higher in LFE than in GCE, due to the higher proportion of isovalerate in the caecum of LFE fed rats.

\section{Impact of the lipo-protein emulsion structure on gut microbiota composition}

Fecal microbiota composition, in terms of phyla (Figure 6A) and alpha diversity, was similar whether the diet was GCE or LFE (data not shown). At lower taxonomic levels, important differences were observed in the three most abundant phyla. In the Firmicutes phylum, abundances of OTUs from Clostridium Cluster XIV, and from Streptococcaceae family, were lower in feces from LFE fed rats compared to GCE (Figure 6B). In contrast, OTUs assigned to the Parabacteroides genus (Bacteroidetes phylum), were significantly more abundant in LFE fed rats (Figure 6C). Moreover, OTUs assigned to Bifidobacterium genus (Actinobacteria phylum) were significantly less abundant in LFE fed rats compared to GCE fed rats. Interestingly, OTUs from the Proteobacteria phylum were strongly impacted at almost all taxonomic levels (Figure S2, A, B, C.1, C.2 and C.3). The most impacted OTUs were from the Gammaproteobacteria class, being more abundant in LFE than in GCE fed rats, and from the Betaproteobacteria class, conversely less abundant in LFE fed rats (Figure S2, A). Among the Betaproteobacteria, , the abundance of Sutterella and Parasutterella genera was decreased in LFE relative to GCE fed rats (Figure S2, B, C.1, C.2, C.3).

\section{DISCUSSION}

Our results clearly indicate that the structure of the lipo-protein emulsion in the diet markedly impacts dietary protein digestion kinetics and the subsequent absorption of amino acids and oligopeptides. Indeed, when compared to the GCE diet, the LFE diet was found to accelerate protein digestion and incorporation of the ${ }^{15} \mathrm{~N}$ label into blood proteins and urea. These differences were paralleled by a rapid and transient increase of the GIP in the portal blood This article is protected by copyright. All rights reserved. 
following LFE diet ingestion. Chronic effects of the lipo-protein emulsion structure in the LFE diet were visible in the distal regions of the GI tract. Indeed, in the ileum, LFE diet increased the expression of cationic AA transporters relative to GCE diet, while in the caecum the structure of the emulsion affected the SCFA composition in association with modification of the fecal microbial ecosystem.

Thus, our current study indicates that the previous data obtained on in vitro digestion [23] with two similar lipo-protein emulsions, can be extrapolated to an in vivo physiological situation.

\section{Digestion kinetics and endocrine response of the gut.}

We observed more rapid digestion kinetics with LFE diet than with GCE diet. This likely results in faster nutrient (AA and peptide) release into the lumen and their subsequent absorption. Solid foods are known to be emptied more slowly than liquid meals when matched for caloric content [36] and macronutrient composition [37], due to the role of the pylorus that allows only small particles to leave the stomach. The increase in consistency and viscosity has also been shown to impact gastric emptying [38], as reported with milk gelation [15] or fermentation [39] that markedly slowed the gastric emptying of proteins. Accordingly, in our study, the texture triggered important differences in $\mathrm{N}$ kinetics. It is noticeable that $1 \mathrm{~h}$ after the meal, $80 \%$ of $\mathrm{N}$ from LFE has already been absorbed subsequently to faster digestion kinetics. This is in agreement with previous studies in humans showing that whey protein is completely emptied from the stomach within $2 \mathrm{~h}$ hours after ingestion, displaying a marked peak of dietary $\mathrm{N}$ appearance in plasmatic AA $[13,40]$. Protein digestibility is mainly driven by intrinsic protein characteristics, such as chemical composition and tridimensional structure that are responsible for resistance to hydrolysis [41]. In the present study, protein This article is protected by copyright. All rights reserved. 
digestibility did not differ between GCE and LFE groups despite important kinetic differences, likely resulting from differences in tridimensional structure between the two lipoprotein emulsions. This discrepancy between digestion kinetic and digestibility had been shown previously in humans in whom delaying gastric emptying by adding sucrose did not modify ileal digestibility of milk protein [42]. In addition, milk protein, both casein and whey, have been found to be the most digestible among dietary proteins [43, 44], whatever their digestion speed, fast for whey and slow for casein. Thus, despite a more rapid kinetic of protein digestion in the LFE diet compared to the GCE diet, we did not observe any difference in dietary $\mathrm{N}$ absorption $5 \mathrm{~h}$ after the meal, this being consistent with the similar weight gain of animals in the two groups.

These differences in digestive kinetics were confirmed by the ${ }^{15} \mathrm{~N}$ appearance in circulating $\mathrm{N}$ pools, with an earlier pic in serum AA, urea and proteins after the LFE meal compared to CGE. This earlier appearance resulted in a lower dietary $\mathrm{N}$ amount in those pools $5 \mathrm{~h}$ after the meal, due to the marginal dietary AA delivery after $1 \mathrm{~h}$. Because the AA afflux was massive within the first hour after the LFE meal, we logically observed a higher transfer of ${ }^{15} \mathrm{~N}$ in the plasma protein pool, reflecting an increased anabolism in the liver. However, as previously shown [40], such a massive afflux also increases the postprandial catabolism of dietary AA, finally resulting in a lower ${ }^{15} \mathrm{~N}$ amount in serum proteins $5 \mathrm{~h}$ after the meal. This result is consistent with previous works showing a better postprandial retention of slow digested proteins compared to rapid proteins [45] [40].

Several gastrointestinal peptides such as GIP, PYY and GLP-1, are secreted from enteroendocrine cells into the circulation in response to food stimuli [46], and are part of the mechanisms regulating gastric emptying rate. However, in this study the postprandial level of PYY and GLP-1 remained unchanged between the two groups while GIP levels increased in the plasma of LFE fed rats. This confirms that the delayed digestion in the stomach of GCE 
fed rats compared to LFE primarily results from gel like texture of GCE diet. GIP is secreted by the intestinal K-cells while PYY and GLP-1 are secreted by the L-cells. K-cells are mainly located in the duodenum and the proximal jejunum while L-cells are found in progressively increasing numbers from the jejunum to the colon [46]. This suggests that by inducing a faster release of nutrients into the lumen, LFE diet impacted the nutrient-sensing by the GIPproducing entero-endocrine cells in the proximal part of the small intestine, but not the entero-endocrine cells located in the distal GI tract. This may be linked to the absence of any significant impact of the emulsion structure on the overall digestibility $5 \mathrm{~h}$ after the test meal as observed in our study. GIP release is well known to be stimulated by carbohydrates and lipids [47]. Despite a less clear mechanism of the K-cell activation by AA or proteins, a previous human study showed a pronounced postprandial increase in GIP as soon as 15 min after the ingestion of whey drink compared to other protein sources [48]. This was associated with the marked raise in leucine, isoleucine, valine, lysine, and threonine in plasma suggesting the potentially crucial role these AA play in whey-induced GIP release [48]. However, subsequent study showed that ingestion of a mixture of these AA failed to stimulated GIP release [49] suggesting that GIP secretion is affected differently by free AA vs AA released from dietary protein, perhaps because of different absorption kinetics.

\section{Chronic effects of the emulsion structure in the distal region of the gut.}

While the lipo-protein emulsion structure did not have acute effects on the endocrine response in the distal region of the gut following the test meal, the chronic ingestion of the two diets during 3 weeks differentially affected the ileum AA transporter expression profile and caecum microbiota metabolic activity and fecal bacteria communities. Despite a similar $\mathrm{N}$ absorption between groups after $5 \mathrm{~h}$, the impact of emulsion structure on digestion kinetics likely affected the nature of proteins or peptides reaching the lower part of the gut and thus the bioavailability of specific AA for the microbiota metabolic activity. This is supported by This article is protected by copyright. All rights reserved. 
the effects that we observed of the emulsion structure on the SCFA composition in the caecum, especially the relative increase in isovalerate under the LFE diet. Since isovalerate is a branched SCFA exclusively produced by deamination of leucine, our results suggests an increased protein fermentation in the caecum after LFE consumption (branched-chain fatty acids are markers of protein fermentation [50]). This effect may also be ascribed to the longer residence time of residual proteins in the caecum that arrive earlier with LFE than with CGE. In addition to isovalerate, the relative amount of butyrate was also higher in the caecum of the LFE fed rats while acetate was decreased compared to the GCE group. Thus, in this study fermentation processes led to various bacterial metabolite profiles associated with, according to the chemical structure and luminal concentrations of metabolites, both detrimental and beneficial effects on the colonic epithelium [51].

The composition of bacterial metabolites in the caecum could also be affected by changes in the microbiota composition and metabolic activity following ingestion of the two different diets: the LFE-fed rats showed an increase in OTUs from the Parabacteroides genus (isovalerate producers) which could also partly explain the increase of the isovalerate percentage measured in the caecum of those rats $[52,53]$. Among the other bacterial groups significantly impacted by the lipo-protein emulsion structure, Sutterella and Parasutterella proportions significantly increased under the GCE diet. Both genera contain bile acids resistant species $[54,55]$. We previously proposed that lipids in GCE diet are less digestible [23] [24]. They may require longer exposure to bile acids in the digestive system for complete absorption. Relative increase in Sutterella and Parasutterella may have resulted from such putative changes in bile acid concentrations or time of exposure. Further work is required to test this hypothesis. It cannot be ruled out whether differences in starch digestion have influenced microbiota composition. Even if starch was mixed with the freeze-dried emulsions without being impacted by the microstructure, interactions might have occurred. 
However, total gastric contents were not significantly different between the two groups $15 \mathrm{~min}$ and $1 \mathrm{~h}$ after the test meal (data not shown). Therefore, since starch is the main component of the diet, it is unlikely that starch digestive kinetics were altered by the emulsion structure.

The two diets also differentially affected gene expression of specific AA transporters in the ileum (Slc6a14, Slc3a1), an effect that was not observed in the jejunum. This confirms our previous work describing similar effect of the lipo-protein emulsion structure on the expression of specific AA transporters only in the lower part of the small intestine [24]. This result suggests that in the LFE group, compared to the GCE group, AA absorption was partly displaced from the proximal to the distal small intestine, probably due to the faster transit of protein. This subsequent rise in the amount of AA in the ileal content might have increased AA fermentation by small intestine bacteria and contributed to the SCFA modifications in the caecum. In the current study, the nutritional status strongly affected the expression of 4 genes encoding for AA transporters (Slc36al, Slc6a19, Slc3al and Slcla2) and the gene encoding the peptide transporter PEPT1. The impact of fasting on PEPT1 had been previously assessed [56], but is less clearly established for most AA transporters. However our data (table S2) clearly demonstrate a significant impact of overnight fasting on Slc6a19, Slc3a1 and Slc1a2. This suggests that the difference in the expression of genes corresponding to the AA transporter may be affected by the nutritional status of the rats.

\section{Conclusions and perspectives}

In conclusion, our study highlights the impact of lipo-protein emulsion structure on gastric emptying, kinetics of protein digestion, and nitrogenous compound absorption and metabolism. The LFE diet, when compared to the GCE diet, accelerated dietary N disposal 
and metabolism and likely as a consequence, modified the microbiota and bacterial metabolite composition in the large intestine. However, these differences were not associated with any difference in the food consumption and body weight. Thus, the modifications in food structure tested here, although impacting important parameters of GI physiology and metabolism, are not sufficient per se to affect such rough endpoints. This is likely explained by the fact that LFE and GCE diets were both well-balanced diets. In the future, in order to evaluate the impact of lipo-protein structure on metabolic and physiological parameters related to the health status it will be important to make lipo-protein emulsion structure in the context of unbalanced diets using different sources or amount of lipids or carbohydrates. To distinguish between deleterious and beneficial effects of the metabolites resulting from bacterial proteolysis, the impact of the lipo-protein emulsion structure should be evaluated on renewal, homeostasis, and barrier function of the colonic epithelium in a long-term perspective [57]. Finally, our data support the idea that food structure and its impact on the digestion kinetics should be taken into account to fully understand the impact of the food on health, and to develop future food products with optimal structure from these points of view.

\section{AUTHOR CONTRIBUTIONS}

F.B, I.S, G.F, V.D, M.L, M.B and C.C designed the study; D.M., S.LF., I.S., C.M. designed food matrix and M.O., S.LF., and I.S., produced food matrix; M.O. and M.B. conducted the in vivo study, M.O., M.B, C.C, V.D., D.J., S.S. and F.D. collected samples, acquired and analyzed data. V.D., M.O., F.B, C.G., M.B., D.J. and M.L. wrote the manuscript.

\section{ACKNOWLEDGMENTS}

This work was funded by a French governmental ANR grant through the Idex Alias program ANR-11-IDEX-0003-02, which also covered Daphné Jaoui, Martin Beaumont and Damien This article is protected by copyright. All rights reserved. 
Mat $\mathrm{PhD}$ fellowships. We are grateful to the INRA MIGALE bioinformatics platform (http://migale.jouy.inra.fr/) for providing computational resources and support and to the Genotoul high-throughput sequencing platform. We also thank Stanislas Mondot for his advices and contribution to the bioinformatics analysis.

The authors have declared no conflicts of interest.

\section{REFERENCES}

[1] Poti, J. M., Mendez, M. A., Ng, S. W., Is the degree of food processing and convenience linked with the nutritional quality of foods purchased by US households? 2015, 101, 12511262.

[2] Monteiro, C. A., Moubarac, J. C., Cannon, G., Ng, S. W., Popkin, B., Ultra-processed products are becoming dominant in the global food system. Obesity reviews : an official journal of the International Association for the Study of Obesity 2013, 14 Suppl 2, 21-28.

[3] Rauber, F., Campagnolo, P. D., Hoffman, D. J., Vitolo, M. R., Consumption of ultraprocessed food products and its effects on children's lipid profiles: a longitudinal study. Nutrition, metabolism, and cardiovascular diseases : NMCD 2015, 25, 116-122.

[4] Pereira, M. A., Kartashov, A. I., Ebbeling, C. B., Van Horn, L., Slattery, M. L., Jacobs, D. R., Jr., Ludwig, D. S., Fast-food habits, weight gain, and insulin resistance (the CARDIA study): 15-year prospective analysis. The Lancet 2005, 365, 36-42.

[5] Fardet, A., Rock, E., Bassama, J., Bohuon, P., Prabhasankar, P., Monteiro, C., Moubarac, J. C., Achir, N., Current food classifications in epidemiological studies do not enable solid nutritional recommendations for preventing diet-related chronic diseases: the impact of food processing. Advances in nutrition (Bethesda, Md.) 2015, 6, 629-638. 
[6] Moubarac, J. C., Parra, D. C., Cannon, G., Monteiro, C. A., Food Classification Systems Based on Food Processing: Significance and Implications for Policies and Actions: A Systematic Literature Review and Assessment. Current obesity reports 2014, 3, 256-272.

[7] Mirmoghtadaie, L., Shojaee Aliabadi, S., Hosseini, S. M., Recent approaches in physical modification of protein functionality. Food chemistry 2016, 199, 619-627.

[8] Foegeding, E. A., Food Protein Functionality--A New Model. Journal of food science 2015, 80, C2670-2677.

[9] Maier, C., Reichert, C. L., Weiss, J., Characterization of Chemically and Thermally Treated Oil-in-Water Heteroaggregates and Comparison to Conventional Emulsions. Journal offood science 2016, 81, E2484-e2491.

[10] Barbé, F., Ménard, O., Gouar, Y. L., Buffière, C., Famelart, M.-H., Laroche, B., Feunteun, S. L., Rémond, D., Dupont, D., Acid and rennet gels exhibit strong differences in the kinetics of milk protein digestion and amino acid bioavailability. Food chemistry 2014, $143,1-8$.

[11] Bourlieu, C., Menard, O., De La Chevasnerie, A., Sams, L., Rousseau, F., Madec, M. N., Robert, B., Deglaire, A., Pezennec, S., Bouhallab, S., Carriere, F., Dupont, D., The structure of infant formulas impacts their lipolysis, proteolysis and disintegration during in vitro gastric digestion. Food chemistry 2015, 182, 224-235.

[12] Mahe, S., Roos, N., Benamouzig, R., Davin, L., Luengo, C., Gagnon, L., Gausserges, N., Rautureau, J., Tome, D., Gastrojejunal kinetics and the digestion of [15N]beta-lactoglobulin and casein in humans: the influence of the nature and quantity of the protein. The American journal of clinical nutrition 1996, 63, 546-552.

[13] Marsset-Baglieri, A., Fromentin, G., Nau, F., Airinei, G., Piedcoq, J., Remond, D., Barbillon, P., Benamouzig, R., Tome, D., Gaudichon, C., The satiating effects of eggs or 
cottage cheese are similar in healthy subjects despite differences in postprandial kinetics. Appetite 2015, 90, 136-143.

[14] Boirie, Y., Dangin, M., Gachon, P., Vasson, M.-P., Maubois, J.-L., Beaufrère, B., Slow and fast dietary proteins differently modulate postprandial protein accretion. Proceedings of the National Academy of Sciences 1997, 94, 14930-14935.

[15] Barbé, F., Ménard, O., Le Gouar, Y., Buffière, C., Famelart, M.-H., Laroche, B., Le Feunteun, S., Dupont, D., Rémond, D., The heat treatment and the gelation are strong determinants of the kinetics of milk proteins digestion and of the peripheral availability of amino acids. Food chemistry 2013, 136, 1203-1212.

[16] Mackie, A. R., Rafiee, H., Malcolm, P., Salt, L., van Aken, G., Specific food structures supress appetite through reduced gastric emptying rate. American journal of physiology. Gastrointestinal and liver physiology 2013, 304, G1038-1043.

[17] Bowen, J., Noakes, M., Clifton, P. M., Appetite regulatory hormone responses to various dietary proteins differ by body mass index status despite similar reductions in ad libitum energy intake. The Journal of clinical endocrinology and metabolism 2006, 91, 2913-2919.

[18] Juvonen, K. R., Karhunen, L. J., Vuori, E., Lille, M. E., Karhu, T., Jurado-Acosta, A., Laaksonen, D. E., Mykkanen, H. M., Niskanen, L. K., Poutanen, K. S., Herzig, K. H., Structure modification of a milk protein-based model food affects postprandial intestinal peptide release and fullness in healthy young men. The British journal of nutrition 2011, 106, $1890-1898$.

[19] Boudry, G., Le Huërou-Luron, I., Michel, C., The Molecular Nutrition of Amino Acids and Proteins, Academic Press, Boston 2016, pp. 207-220.

[20] Blachier, F., Mariotti, F., Huneau, J. F., Tome, D., Effects of amino acid-derived luminal metabolites on the colonic epithelium and physiopathological consequences. Amino acids $2007,33,547-562$.

This article is protected by copyright. All rights reserved. 
[21] Duncan, S. H., Belenguer, A., Holtrop, G., Johnstone, A. M., Flint, H. J., Lobley, G. E., Reduced Dietary Intake of Carbohydrates by Obese Subjects Results in Decreased Concentrations of Butyrate and Butyrate-Producing Bacteria in Feces. Applied and Environmental Microbiology 2007, 73, 1073-1078.

[22] Davila, A. M., Blachier, F., Gotteland, M., Andriamihaja, M., Benetti, P. H., Sanz, Y., Tome, D., Intestinal luminal nitrogen metabolism: role of the gut microbiota and consequences for the host. Pharmacological research 2013, 68, 95-107.

[23] Mat, D. J. L., Le Feunteun, S., Michon, C., Souchon, I., In vitro digestion of foods using $\mathrm{pH}$-stat and the INFOGEST protocol: Impact of matrix structure on digestion kinetics of macronutrients, proteins and lipids. Food Research International 2016, 88, PartB, 226-233.

[24] Beaumont, M., Jaoui, D., Douard, V., Mat, D., Koeth, F., Goustard, B., Mayeur, C., Mondot, S., Hovaghimian, A., Feunteun, S. L., Chaumontet, C., Davila, A. M., Tome, D., Souchon, I., Michon, C., Fromentin, G., Blachier, F., Leclerc, M., Structure of protein emulsion in food impacts intestinal microbiota, caecal luminal content composition and distal intestine characteristics in rats. Molecular nutrition \& food research 2017. May 17. doi: 10.1002/mnfr.201700078. [Epub ahead of print].

[25] Oberli, M., Lan, A., Khodorova, N., Sante-Lhoutellier, V., Walker, F., Piedcoq, J., Davila, A. M., Blachier, F., Tome, D., Fromentin, G., Gaudichon, C., Compared with Raw Bovine Meat, Boiling but Not Grilling, Barbecuing, or Roasting Decreases Protein Digestibility without Any Major Consequences for Intestinal Mucosa in Rats, although the Daily Ingestion of Bovine Meat Induces Histologic Modifications in the Colon. The Journal of nutrition 2016, 146, 1506-1513.

[26] Bos, C., Airinei, G., Mariotti, F., Benamouzig, R., Bérot, S., Evrard, J., Fénart, E., Tomé, D., Gaudichon, C., The Poor Digestibility of Rapeseed Protein Is Balanced by Its Very High Metabolic Utilization in Humans. The Journal of nutrition 2007, 137, 594-600. 
[27] Bos, C., Stoll, B., Fouillet, H., Gaudichon, C., Guan, X., Grusak, M. A., Reeds, P. J., Burrin, D. G., Tome, D., Postprandial intestinal and whole body nitrogen kinetics and distribution in piglets fed a single meal. American journal of physiology. Endocrinology and metabolism 2005, 288, E436-446.

[28] Oberli, M., Marsset-Baglieri, A., Airinei, G., Sante-Lhoutellier, V., Khodorova, N., Remond, D., Foucault-Simonin, A., Piedcoq, J., Tome, D., Fromentin, G., Benamouzig, R., Gaudichon, C., High True Ileal Digestibility but Not Postprandial Utilization of Nitrogen from Bovine Meat Protein in Humans Is Moderately Decreased by High-Temperature, LongDuration Cooking. The Journal of nutrition 2015, 145, 2221-2228.

[29] Kristensen, N. B., Pierzynowski, S. G., Danfaer, A., Net portal appearance of volatile fatty acids in sheep intraruminally infused with mixtures of acetate, propionate, isobutyrate, butyrate, and valerate. Journal of animal science 2000, 78, 1372-1379.

[30] Magoc, T., Salzberg, S. L., FLASH: fast length adjustment of short reads to improve genome assemblies. Bioinformatics (Oxford, England) 2011, 27, 2957-2963.

[31] Fass, J. N., Joshi, N. A., Couvillion, M. T., Bowen, J., Gorovsky, M. A., Hamilton, E. P., Orias, E., Hong, K., Coyne, R. S., Eisen, J. A., Chalker, D. L., Lin, D., Collins, K., GenomeScale Analysis of Programmed DNA Elimination Sites in Tetrahymena thermophila. G3 (Bethesda, Md.) 2011, 1, 515-522.

[32] Bankevich, A., Nurk, S., Antipov, D., Gurevich, A. A., Dvorkin, M., Kulikov, A. S., Lesin, V. M., Nikolenko, S. I., Pham, S., Prjibelski, A. D., Pyshkin, A. V., Sirotkin, A. V., Vyahhi, N., Tesler, G., Alekseyev, M. A., Pevzner, P. A., SPAdes: a new genome assembly algorithm and its applications to single-cell sequencing. Journal of computational biology : a journal of computational molecular cell biology 2012, 19, 455-477.

[33] Cole, J. R., Wang, Q., Cardenas, E., Fish, J., Chai, B., Farris, R. J., Kulam-SyedMohideen, A. S., McGarrell, D. M., Marsh, T., Garrity, G. M., Tiedje, J. M., The Ribosomal This article is protected by copyright. All rights reserved. 
Database Project: improved alignments and new tools for rRNA analysis. Nucleic acids research 2009, 37, D141-145.

[34] Bokulich, N. A., Subramanian, S., Faith, J. J., Gevers, D., Gordon, J. I., Knight, R., Mills, D. A., Caporaso, J. G., Quality-filtering vastly improves diversity estimates from Illumina amplicon sequencing. Nature methods 2013, 10, 57-59.

[35] McMurdie, P. J., Holmes, S., phyloseq: an R package for reproducible interactive analysis and graphics of microbiome census data. PloS one 2013, 8, e61217.

[36] Maes, B. D., Ghoos, Y. F., Geypens, B. J., Hiele, M. I., Rutgeerts, P. J., Relation between gastric emptying rate and energy intake in children compared with adults. Gut 1995, $36,183-188$.

[37] Malagelada, J. R., Go, V. L., Summerskill, W. H., Different gastric, pancreatic, and biliary responses to solid-liquid or homogenized meals. Digestive diseases and sciences $1979,24,101-110$.

[38] Houghton, L. A., Hickson, F., Read, N. W., Effect of food consistency on gastric emptying in man. Gut 1987, 28, 1584-1588.

[39] Gaudichon, C., Roos, N., Mahe, S., Sick, H., Bouley, C., Tome, D., Gastric emptying regulates the kinetics of nitrogen absorption from $15 \mathrm{~N}$-labeled milk and $15 \mathrm{~N}$-labeled yogurt in miniature pigs. The Journal of nutrition 1994, 124, 1970-1977.

[40] Lacroix, M., Bos, C., Leonil, J., Airinei, G., Luengo, C., Dare, S., Benamouzig, R., Fouillet, H., Fauquant, J., Tome, D., Gaudichon, C., Compared with casein or total milk protein, digestion of milk soluble proteins is too rapid to sustain the anabolic postprandial amino acid requirement. The American journal of clinical nutrition 2006, 84, 1070-1079.

[41] Dallas, D. C., Underwood, M. A., Zivkovic, A. M., German, J. B., Digestion of Protein in Premature and Term Infants. Journal of nutritional disorders \& therapy 2012, 2, 112. 
[42] Gaudichon, C., Mahe, S., Benamouzig, R., Luengo, C., Fouillet, H., Dare, S., Van Oycke, M., Ferriere, F., Rautureau, J., Tome, D., Net postprandial utilization of [15N]labeled milk protein nitrogen is influenced by diet composition in humans. The Journal of nutrition 1999, 129, 890-895.

[43] Rutherfurd, S. M., Fanning, A. C., Miller, B. J., Moughan, P. J., Protein digestibilitycorrected amino acid scores and digestible indispensable amino acid scores differentially describe protein quality in growing male rats. The Journal of nutrition 2015, 145, 372-379.

[44] Tome, D., Criteria and markers for protein quality assessment - a review. The British journal of nutrition 2012, 108 Suppl 2, S222-229.

[45] Dangin, M., Boirie, Y., Garcia-Rodenas, C., Gachon, P., Fauquant, J., Callier, P., Ballevre, O., Beaufrere, B., The digestion rate of protein is an independent regulating factor of postprandial protein retention. American journal of physiology. Endocrinology and metabolism 2001, 280, E340-348.

[46] Furness, J. B., Rivera, L. R., Cho, H.-J., Bravo, D. M., Callaghan, B., The gut as a sensory organ. Nat Rev Gastroenterol Hepatol 2013, 10, 729-740.

[47] Pais, R., Gribble, F. M., Reimann, F., Stimulation of incretin secreting cells. Therapeutic advances in endocrinology and metabolism 2016, 7, 24-42.

[48] Nilsson, M., Stenberg, M., Frid, A. H., Holst, J. J., Björck, I. M., Glycemia and insulinemia in healthy subjects after lactose-equivalent meals of milk and other food proteins: the role of plasma amino acids and incretins. The American journal of clinical nutrition 2004, $80,1246-1253$.

[49] Nilsson, M., Holst, J. J., Bjorck, I. M., Metabolic effects of amino acid mixtures and whey protein in healthy subjects: studies using glucose-equivalent drinks. The American journal of clinical nutrition 2007, 85, 996-1004.

This article is protected by copyright. All rights reserved. 
[50] Windey, K., De Preter, V., Verbeke, K., Relevance of protein fermentation to gut health. Molecular nutrition \& food research 2012, 56, 184-196.

[51] Portune, K. J., Beaumont, M., Davila, A.-M., Tomé, D., Blachier, F., Sanz, Y., Gut microbiota role in dietary protein metabolism and health-related outcomes: The two sides of the coin. Trends in Food Science \& Technology 2016, 57, 213-232.

[52] Song, Y., Liu, C., Lee, J., Bolanos, M., Vaisanen, M. L., Finegold, S. M., "Bacteroides goldsteinii sp. nov." isolated from clinical specimens of human intestinal origin. Journal of clinical microbiology 2005, 43, 4522-4527.

[53] Sakamoto, M., Benno, Y., Reclassification of Bacteroides distasonis, Bacteroides goldsteinii and Bacteroides merdae as Parabacteroides distasonis gen. nov., comb. nov., Parabacteroides goldsteinii comb. nov. and Parabacteroides merdae comb. nov. International journal of systematic and evolutionary microbiology 2006, 56, 1599-1605.

[54] Morotomi, M., Nagai, F., Watanabe, Y., Parasutterella secunda sp. nov., isolated from human faeces and proposal of Sutterellaceae fam. nov. in the order Burkholderiales. International journal of systematic and evolutionary microbiology 2011, 61, 637-643.

[55] Wexler, H. M., Reeves, D., Summanen, P. H., Molitoris, E., Mcteague, M., Duncan, J., Wilson, K. H., Finegold, S. M., Sutterella wadsworthensis gen. nov., sp. nov., Bile-Resistant Microaerophilic Campylobacter gracilis-Like Clinical Isolates. International journal of systematic and evolutionary microbiology 1996, 46, 252-258.

[56] Naruhashi, K., Sai, Y., Tamai, I., Suzuki, N., Tsuji, A., PepT1 mRNA expression is induced by starvation and its level correlates with absorptive transport of cefadroxil longitudinally in the rat intestine. Pharmaceutical research 2002, 19, 1417-1423.

[57] Blachier, F., Beaumont, M., Andriamihaja, M., Davila, A. M., Lan, A., Grauso, M., Armand, L., Benamouzig, R., Tome, D., Changes in the Luminal Environment of the Colonic 
Epithelial Cells and Physiopathological Consequences. The American journal of pathology $2017,187,476-486$.

\section{TABLES}

Table 1: Composition of the experimental diets

\begin{tabular}{ll}
\hline Ingredients & $g / k g$ (dry matter) \\
\hline Whey protein isolate* & 165.3 \\
Rapeseed oil* & 110.2 \\
Corn starch & 489.7 \\
Sucrose & 79.7 \\
Cellulose & 50 \\
Choline & 2.3 \\
Vitamin mixture, AIN 93-V & 10 \\
Mineral mixture, AIN 93-M & 35 \\
\hline Energy & \\
\hline Energy density ( $k J / g)$ & 16.7 \\
Carbohydrate (\% energy) & 53 \\
Protein (\% energy) & 20 \\
Fat (\% energy) & 26 \\
$*$ Indicates ingredients included in the emulsion
\end{tabular}

This article is protected by copyright. All rights reserved. 
Table 2: Peripheral plasma metabolites LFE: liquid fine emulsion; GCE: gelled coarse emulsion, NEFA: non-esterified fatty acids. Values are mean \pm SEM. Means were compared with two way ANOVA test, NS: not statistically significant $(\mathrm{p}>0.05)$. T: time effect, E: emulsion structure effect, E x T: interaction effect.

\begin{tabular}{|c|c|c|c|c|c|c|c|c|c|c|c|}
\hline & \multicolumn{2}{|c|}{ fasting } & \multicolumn{2}{|c|}{$15 \mathrm{~min}$ after feeding } & \multicolumn{2}{|c|}{ 1h after feeding } & \multicolumn{2}{|c|}{$5 \mathrm{~h}$ after feeding } & \multicolumn{3}{|c|}{ significance } \\
\hline & GCE & LFE & GCE & LFE & GCE & LFE & GCE & LFE & $\mathrm{T}$ & $\mathrm{E}$ & $\mathrm{E} \times \mathrm{T}$ \\
\hline Urea (mmol/L) & $6.76 \pm 0.15^{b}$ & $6.64 \pm 0.27^{\mathrm{ab}}$ & $7.56 \pm 0.49^{b}$ & $7.36 \pm 0.36^{\mathrm{ab}}$ & $8.10 \pm 0.49^{b}$ & $7.92 \pm 0.44^{b}$ & $8.00 \pm 0.58^{b}$ & $5.58 \pm 0.23^{\mathrm{a}}$ & 0.006 & 0.012 & 0.017 \\
\hline Triglyceride (mmol/L) & $0.63 \pm 0.09^{a}$ & $0.77 \pm 0.11^{\mathrm{a}}$ & $0.73 \pm 0.10^{\mathrm{a}}$ & $0.68 \pm 0.15^{\mathrm{a}}$ & $2.61 \pm 0.50^{b}$ & $2.08 \pm 0.49^{b}$ & $0.96 \pm 0.14^{\mathrm{ab}}$ & $0.60 \pm 0.03^{a}$ & $<0.0001$ & NS & NS \\
\hline NEFA (mmol/L) & $0.25 \pm 0.04^{a b}$ & $0.26 \pm 0.04^{\mathrm{ab}}$ & $0.21 \pm 0.04^{\mathrm{a}}$ & $0.16 \pm 0.04^{\mathrm{a}}$ & $0.49 \pm 0.05^{b}$ & $0.47 \pm 0.09^{b}$ & $0.31 \pm 0.06^{\mathrm{ab}}$ & $0.37 \pm 0.09^{a b}$ & 0.0002 & NS & NS \\
\hline Glucose $(\mathrm{mmol} / \mathrm{L})$ & $11.76 \pm 0.64$ & $12.55 \pm 0.78$ & $10.70 \pm 0.65$ & $13.47 \pm 2.08$ & $12.22 \pm 0.58$ & $12.34 \pm 1.49$ & $14.56 \pm 1.22$ & $13.21 \pm 0.46$ & NS & NS & NS \\
\hline
\end{tabular}

Means with different superscript letters are significantly different from others in the same row ( $\mathrm{P}<0.05$ by posthoc HSD Tukey)

Received: 05/07/2017; Revised: 04/09/2017; Accepted: 27/09/2017

This article has been accepted for publication and undergone full peer review but has not been through the copyediting, typesetting, pagination and proofreading process, which may lead to differences between this version and the Version of Record. Please cite this article as doi: 10.1002/mnfr.201700570. This article is protected by copyright. All rights reserved. 
Table 3: AA and peptide transporter gene expression in the jejunum and ileum after overnight fasting and $5 \mathrm{~h}$ after re-feeding. LFE: liquid fine emulsion; GCE: gelled coarse emulsion. Values are mean \pm SEM. Means were compared with two-way ANOVA, NS: not statistically significant ( $p$ > 0.05). T: time effect, E: emulsion structure effect, E x T: interaction effect. Data were normalized relative to levels seen in GCE fasted group in jejunum and ileum.

\begin{tabular}{|c|c|c|c|c|c|c|c|c|c|c|c|c|c|c|}
\hline & \multicolumn{7}{|c|}{ Jejunum } & \multicolumn{7}{|c|}{ Ileum } \\
\hline \multirow{2}{*}{$\begin{array}{l}\text { Transporter name } \\
\text { (peptides or AA } \\
\text { transported) }\end{array}$} & \multicolumn{2}{|c|}{ Fasted } & \multicolumn{2}{|c|}{$5 \mathrm{~h}$ after feeding } & \multicolumn{3}{|c|}{ Statistics } & \multicolumn{2}{|c|}{ Fasted } & \multicolumn{2}{|c|}{$5 \mathrm{~h}$ after feeding } & \multicolumn{3}{|c|}{ Statistics } \\
\hline & GCE & LFE & GCE & LFE & $\mathrm{T}$ & $\mathrm{E}$ & TxE & GCE & LFE & GCE & LFE & $\mathrm{T}$ & $\mathrm{E}$ & TxE \\
\hline Apical transporters: & & & & & & & & & & & & & & \\
\hline $\begin{array}{l}\text { Peptide transporter } \\
\text { PEPT1 (Slc15a1) di \& } \\
\text { tri peptides }\end{array}$ & $1.00 \pm 0.01^{\mathrm{a}}$ & $1.03 \pm 0.10^{\mathrm{ab}}$ & $0.66 \pm 0.05^{\mathrm{b}}$ & $0.68 \pm 0.12^{\mathrm{ab}}$ & 0.001 & NS & NS & $1,00 \pm 0.05^{\mathrm{ab}}$ & $1,11 \pm 0.10^{\mathrm{a}}$ & $0,86 \pm 0.02^{\mathrm{ab}}$ & $0,86 \pm 0.04^{b}$ & 0.006 & NS & NS \\
\hline $\begin{array}{l}\text { System B }^{\mathbf{0}}(\text { Slc6a19 }) \\
\text { neutral AA }\end{array}$ & $1.00 \pm 0.15^{\mathrm{ab}}$ & $1.27 \pm 0.21^{\mathrm{a}}$ & $0.71 \pm 0.04^{\mathrm{ab}}$ & $0.63 \pm 0.07^{b}$ & 0.003 & NS & NS & $1,00 \pm 0.04$ & $0,98 \pm 0.10$ & $1,07 \pm 0.08$ & $1,06 \pm 0.15$ & NS & NS & NS \\
\hline $\begin{array}{l}\text { Imino acid carrier } \\
\text { (Slc36a1) } \\
\text { Imino acids. glycine. } \\
\text { alanine. taurine }\end{array}$ & $1.00 \pm 0.01$ & $0.94 \pm 0.20$ & $0.62 \pm 0.11$ & $0.56 \pm 0.11$ & 0.009 & NS & NS & $1,00 \pm 0.11$ & $1,12 \pm 0.12$ & $1,01 \pm 0.10$ & $0,91 \pm 0.06$ & NS & NS & NS \\
\hline
\end{tabular}

This article is protected by copyright. All rights reserved. 


\begin{tabular}{|c|c|c|c|c|c|c|c|c|c|c|c|c|c|c|}
\hline $\begin{array}{l}\text { System Bo.+ }^{\text {o. Slc6a14 })} \\
\text { neutral and cationic AA }\end{array}$ & $1.00 \pm 0.23$ & $1.13 \pm 0.16$ & $1.16 \pm 0.13$ & $1.41 \pm 0.30$ & NS & NS & NS & $1.00 \pm 0.11^{\mathrm{a}}$ & $1,39 \pm 0.10^{b}$ & $0,76 \pm 0.06^{a}$ & $0,97 \pm 0.07^{\mathrm{a}}$ & 0.004 & 0.002 & NS \\
\hline $\begin{array}{l}\text { SystemASC (Slc1a5) } \\
\text { alanine. serine. cystine. } \\
\text { threonine. glutamine }\end{array}$ & $1.00 \pm 0.12$ & $0.92 \pm 0.05$ & $0.88 \pm 0.04$ & $1.13 \pm 0.15$ & NS & NS & 0.049 & $1,00 \pm 0.22$ & $1,30 \pm 0.35$ & $0,78 \pm 0.09$ & $0,84 \pm 0.07$ & NS & NS & NS \\
\hline $\begin{array}{l}\text { System bo.+ (Slc3a1) } \\
\text { cationic AA. cystine }\end{array}$ & $1.00 \pm 0.06$ & $1.08 \pm 0.11$ & $0.80 \pm 0.09$ & $0.93 \pm 0.02$ & 0.030 & NS & NS & $1,00 \pm 0.06^{\mathrm{ab}}$ & $1,25 \pm 0.10^{a}$ & $0,89 \pm 0.03^{b}$ & $1,10 \pm 0.05^{\mathrm{ab}}$ & 0.073 & 0.004 & NS \\
\hline $\begin{array}{l}\text { System } \mathbf{X}_{\mathbf{A G}}^{-}(\text {Slc1aI }) \\
\text { anionic AA }\end{array}$ & $1.00 \pm 0.17$ & $1.06 \pm 0.18$ & $1.08 \pm 0.08$ & $1.09 \pm 0.11$ & NS & NS & NS & $1,00 \pm 0.09$ & $\begin{array}{l}1,27 \pm \\
0.20\end{array}$ & $0,99 \pm 0.09$ & $1,17 \pm 0.09$ & NS & 0.062 & NS \\
\hline $\begin{array}{l}\text { Basolateral } \\
\text { transporters: }\end{array}$ & & & & & & & & & & & & & & \\
\hline $\begin{array}{l}\text { System A (Slc38a2) } \\
\text { neutral and imino AA }\end{array}$ & $1.00 \pm 0.07$ & $0.98 \pm 0.02$ & $0.87 \pm 0.09$ & $1.29 \pm 0.30$ & NS & NS & NS & $1,00 \pm 0.09$ & $1,12 \pm 0.12$ & $0,92 \pm 0.06$ & $1,11 \pm 0.03$ & NS & 0.089 & NS \\
\hline $\begin{array}{l}\text { System X }{ }_{\mathrm{AG}}^{-}(\text {Slc1a2) } \\
\text { anionic } A A\end{array}$ & $1.00 \pm 0.08$ & $0.64 \pm 0.13$ & $0.75 \pm 0.11$ & $0.94 \pm 0.06$ & NS & NS & 0.016 & $1,00 \pm 0.06$ & $2,28 \pm 1.08$ & $1,20 \pm 0.15$ & $1,17 \pm 0.19$ & NS & NS & NS \\
\hline
\end{tabular}

Means with different superscript letters are significantly different from others in the same row $(\mathrm{P}<0.05$ by posthoc HSD Tukey) 
Table 4: Short chain fatty acids produced by microbiota in the caecum. LFE: liquid fine emulsion; GCE: gelled coarse emulsion, SCFA: short chain fatty acids, AA: amino-acid. SCFA specifically derived from AA includes isobutyrate, isovalerate and valerate. Values are mean \pm SEM. Means were compared by two- way ANOVA, NS: not statistically significant ( $p>0.05)$.

\begin{tabular}{|c|c|c|c|c|c|c|c|}
\hline & \multicolumn{2}{|c|}{ fasted } & \multicolumn{2}{|c|}{$5 \mathrm{~h}$ after feeding } & & & \\
\hline & GCE $(n=5)$ & $\operatorname{LFE}(n=3)$ & GCE $(n=4)$ & $\operatorname{LFE}(n=5)$ & \multicolumn{3}{|c|}{$P$ value } \\
\hline SCFA composition ( $\%$ of total SCFA) & & & & & Emulsion & Time & interaction \\
\hline Acétate & $65,69 \pm 0.96^{\mathrm{ab}}$ & $61,84 \pm 1.1^{\mathrm{a}}$ & $67,99 \pm 1.29^{b}$ & $62,42 \pm 0.98^{a}$ & 0.0015 & NS & NS \\
\hline Propionate & $21,45 \pm 1.04$ & $19,16 \pm 0.79$ & $19,90 \pm 0.82$ & $20,33 \pm 0.68$ & NS & NS & NS \\
\hline Isobutyrate & $1,66 \pm .12$ & $1,58 \pm 0.25$ & $1,27 \pm 0.08$ & $1,42 \pm 0.03$ & NS & NS & NS \\
\hline Butyrate & $7,25 \pm 0.79^{a}$ & $11,35 \pm 0.79^{b}$ & $7,59 \pm 0.47^{\mathrm{a}}$ & $9,42 \pm 0.74^{\mathrm{ab}}$ & 0.0006 & NS & NS \\
\hline Isovalérate & $1,10 \pm 0.14^{\mathrm{a}}$ & $3,05 \pm 0.59^{b}$ & $0,90 \pm 0.08^{\mathrm{a}}$ & $3,40 \pm 0.40^{b}$ & $<0.0001$ & NS & NS \\
\hline Valérate & $2,23 \pm 0.16$ & $2,43 \pm 0.16$ & $1,96 \pm 0.14$ & $2,33 \pm 0.10$ & NS & NS & NS \\
\hline Caproate & $0,63 \pm 0.17$ & $0,59 \pm 0.12$ & $0,38 \pm 0.08$ & $0,68 \pm 0.38$ & NS & NS & NS \\
\hline SCFA specifically derived from AA & $5,61 \pm 0.55^{\mathrm{ab}}$ & $7,65 \pm 0.91^{\mathrm{ab}}$ & $4,52 \pm 0.23^{a}$ & $7,84 \pm 0.68^{b}$ & 0.0021 & NS & NS \\
\hline
\end{tabular}

Means with different superscript letters are significantly different from others in the same row ( $\mathrm{P}<0.05$ by posthoc HSD Tukey) 


\section{FIGURE LEGENDS}

Figure 1: Design of the three weeks feeding experiment (A) and of the test meal experiment

(B). LFE: liquid fine emulsion; GCE: gelled coarse emulsion.

\section{Figure 1}

A

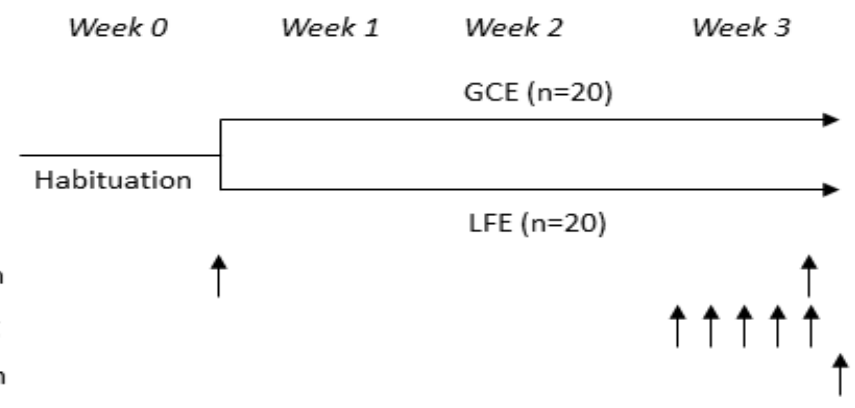

B Calibrated meal with

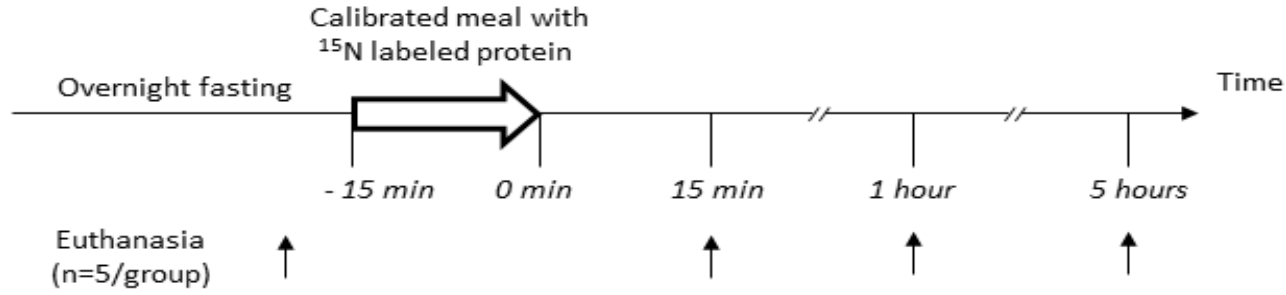

Received: 05/07/2017; Revised: 04/09/2017; Accepted: 27/09/2017

This article has been accepted for publication and undergone full peer review but has not been through the copyediting, typesetting, pagination and proofreading process, which may lead to differences between this version and the Version of Record. Please cite this article as doi: 10.1002/mnfr.201700570.

This article is protected by copyright. All rights reserved. 
Figure 2: Dietary $\mathrm{N}$ recovered after $15 \mathrm{~min}, 1 \mathrm{~h}$ or $5 \mathrm{~h}$ of digestion of the ${ }^{15} \mathrm{~N}$-labelled test meal from the stomach (A), the small intestine (B), the cecum (C) and the colon (D) of rats fed for 3 weeks the diets containing the LFE or the GCE. Values are means \pm SEM $(\mathrm{n}=5$ /group). $*$ indicates a significant difference among groups $(\mathrm{p}<0.05)$. LFE: liquid fine emulsion; GCE: gelled coarse emulsion. 
Figure 2

(1)

GCE

$\square$ LFE

A

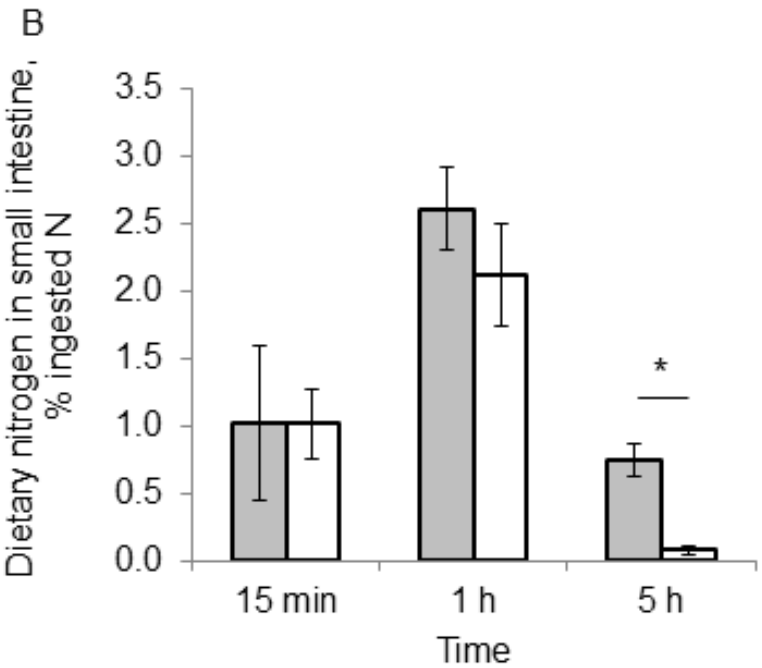

C

D
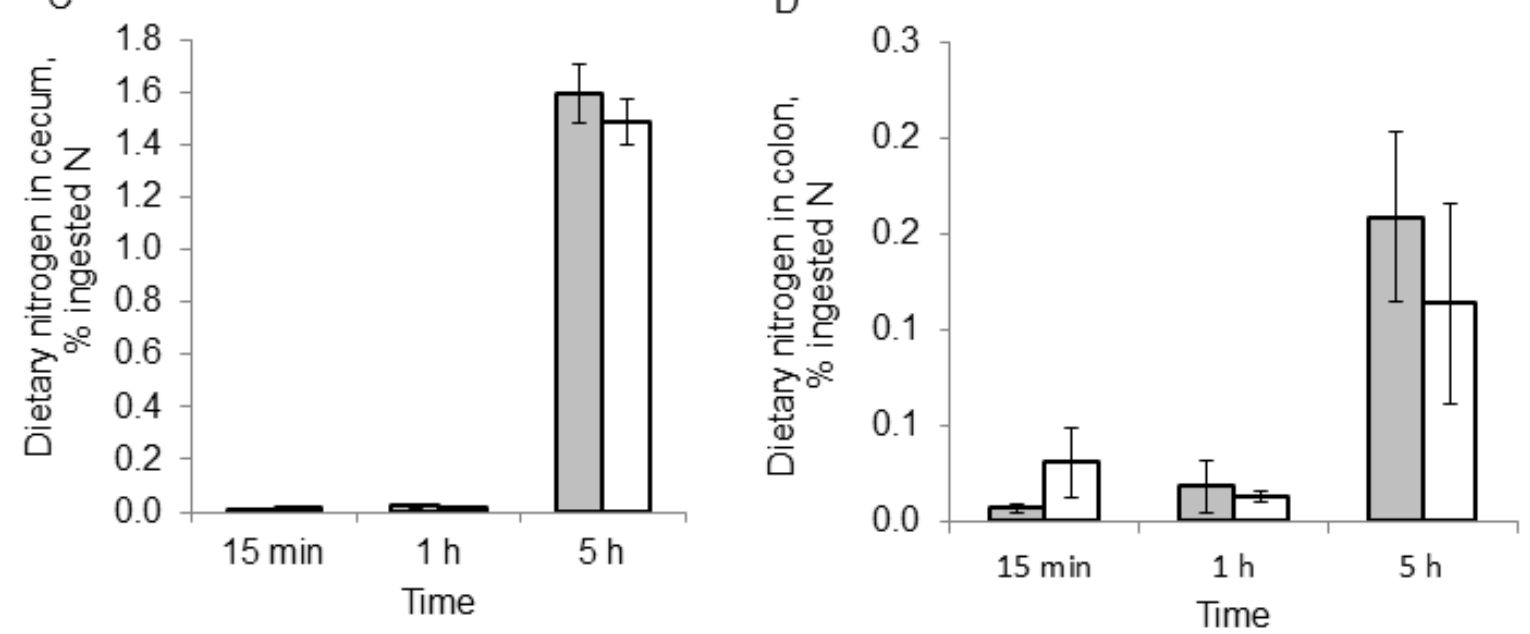

This article is protected by copyright. All rights reserved.

Comment citer ce document 
Figure 3: Absorption of dietary $\mathrm{N}$ in rats $15 \mathrm{~min}, 1 \mathrm{~h}$ and $5 \mathrm{~h}$ after the ${ }^{15} \mathrm{~N}$-labelled test meal.

* indicates a significant difference among groups. LFE: liquid fine emulsion; GCE: gelled coarse emulsion.

\section{Figure 3}

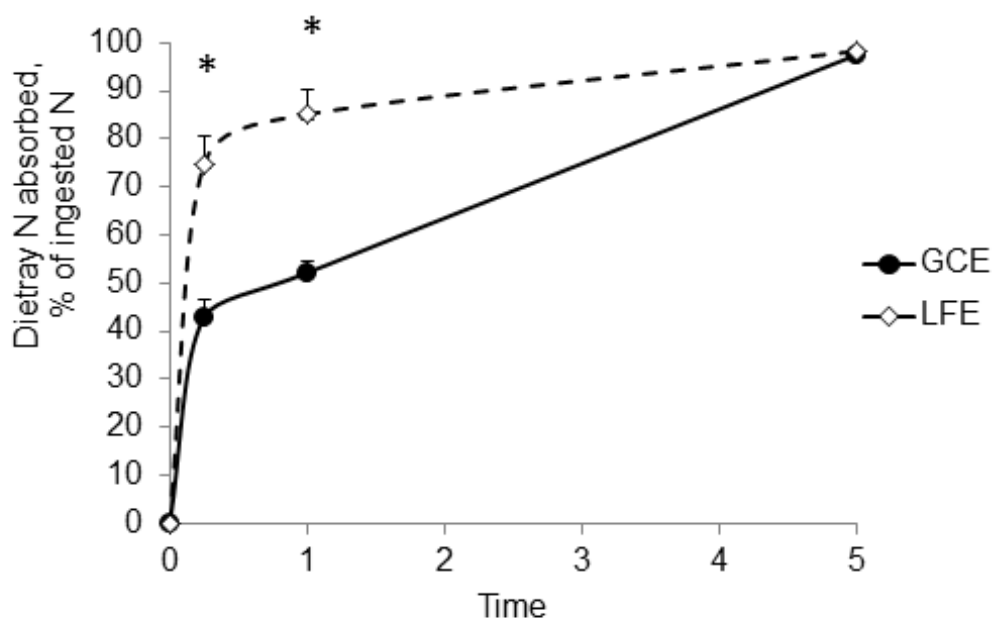

This article is protected by copyright. All rights reserved.

Comment citer ce document 
Figure 4: Incorporation of dietary $\mathrm{N}$ in serum proteins (A), serum amino acids (B) and body urea $(\mathrm{C})$ in fasted rats or $15 \mathrm{~min}, 1 \mathrm{~h}$ or $5 \mathrm{~h}$ after the ${ }^{15} \mathrm{~N}$-labelled test meal. Values are means \pm SEM ( $n=5 /$ group). * indicates a significant difference among groups. LFE: liquid fine emulsion; GCE: gelled coarse emulsion. APE: atom percent excess; AA: amino acid. 


\section{Figure 4}

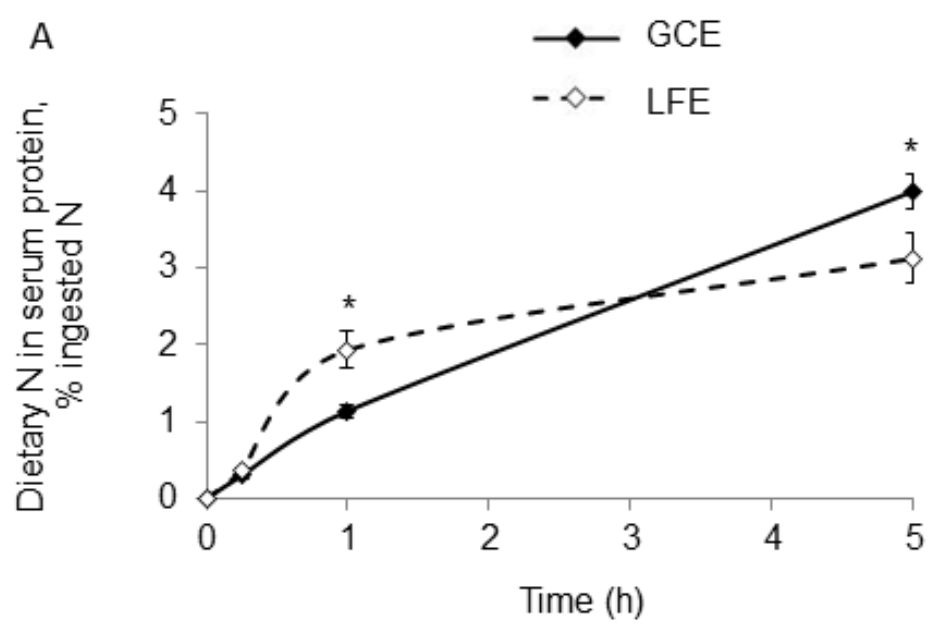

B

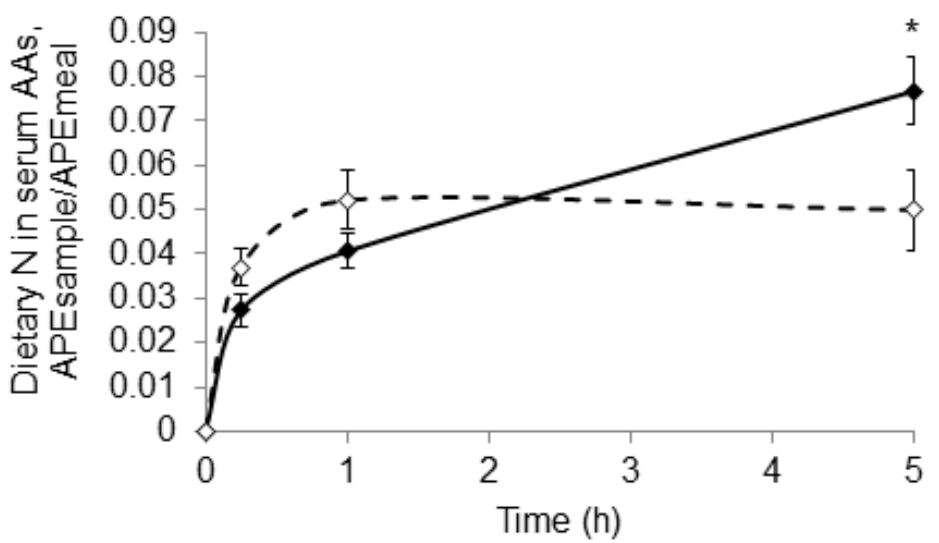

$\mathrm{C}$

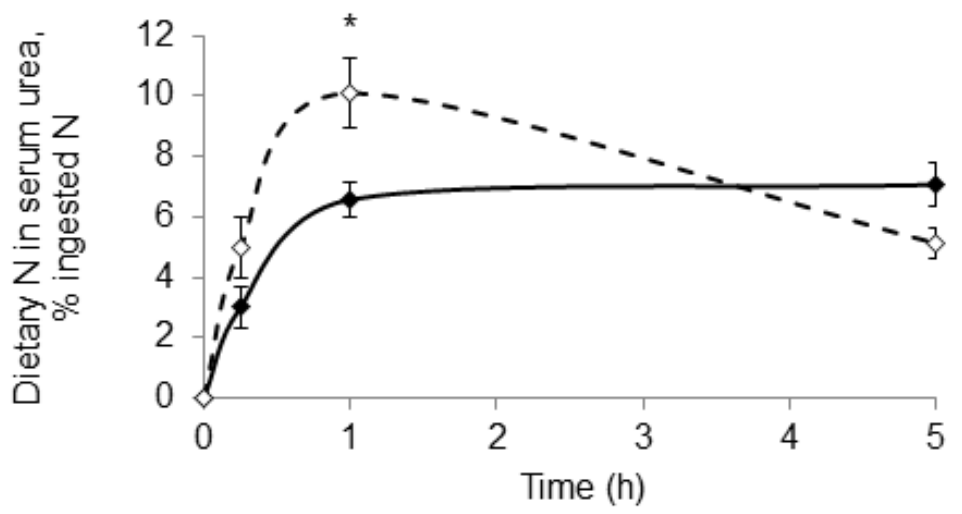

This article is protected by copyright. All rights reserved.

Comment citer ce document 
Figure 5: Portal blood concentration of gastric inhibitory polypeptide (GIP) (A), glucagonlike peptide 1 (GLP-1) (B), peptide YY (PYY) (C), glucagon (D) and leptin (E) in fasted rats or $15 \mathrm{~min}, 1 \mathrm{~h}$ or $5 \mathrm{~h}$ after the ${ }^{15} \mathrm{~N}$-labelled test meal. Values are means \pm SEMs $(\mathrm{n}=3$ 5/group). * indicates a significant difference among groups. LFE: liquid fine emulsion; GCE: gelled coarse emulsion. 


\section{Figure 5}
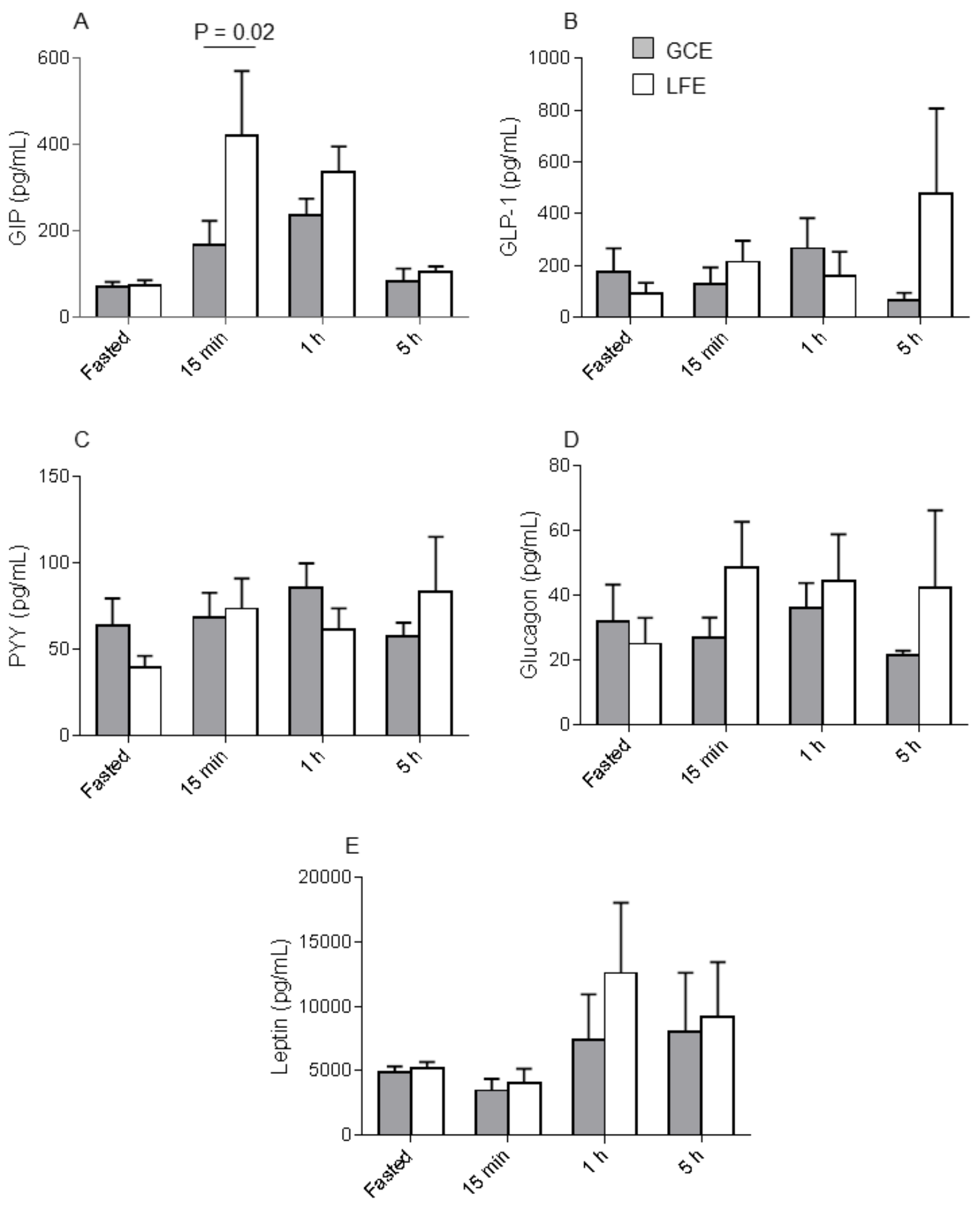

This article is protected by copyright. All rights reserved.

Comment citer ce document 
Figure 6: Microbiota composition after three weeks under LFE or GCE diet. Most abundant Phyla (A). Most abundant families from the Firmicutes phylum (B); the left inset indicates impacted members of the Clostridium Cluster IV (from the Ruminococcaceae Family); the right inset indicates impacted Streptococcaceae Family. Most abundant families from the Bacteroidetes phylum (C); inset impacted Parabacteroides genus (from the Porphyromonadaceae Family). Impacted Bifidobacterium genus from the Actinobacteria phylum (D). For all plots, the Y-axis refers to relative normalized abundances. Normalized counts were compared with Wald test, and p-values were adjusted using Benjamini Hochberg correction $(n=15-16)$. LFE: liquid fine emulsion; GCE: gelled coarse emulsion. 


\section{Figure 6}
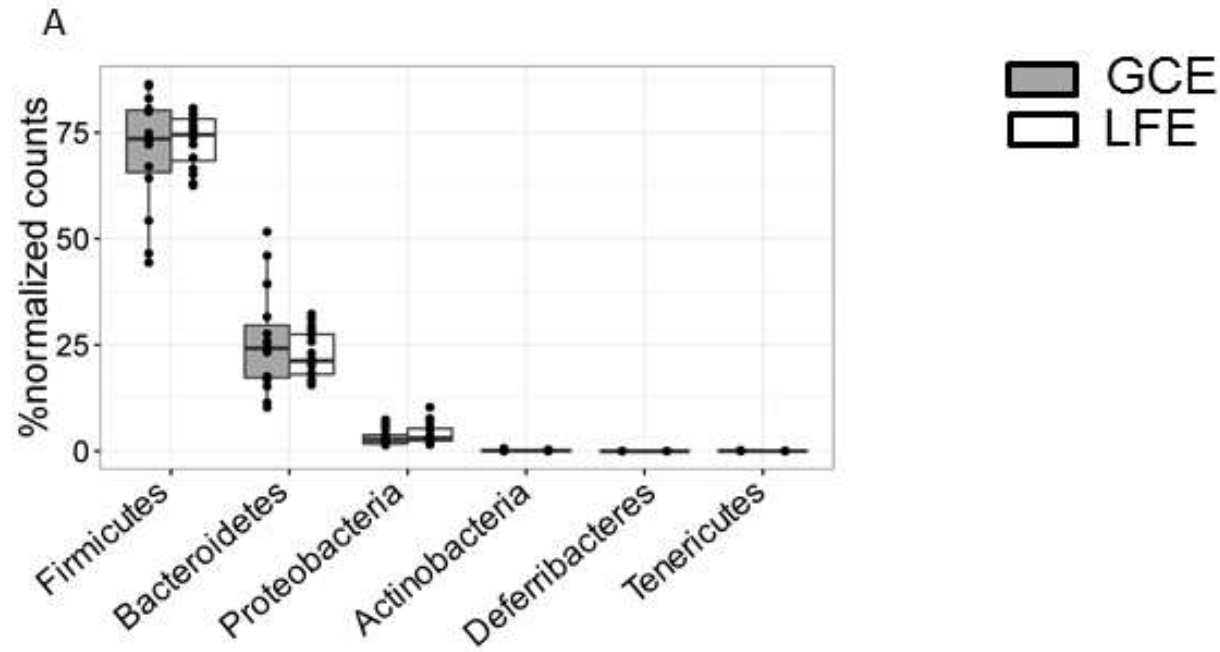

B

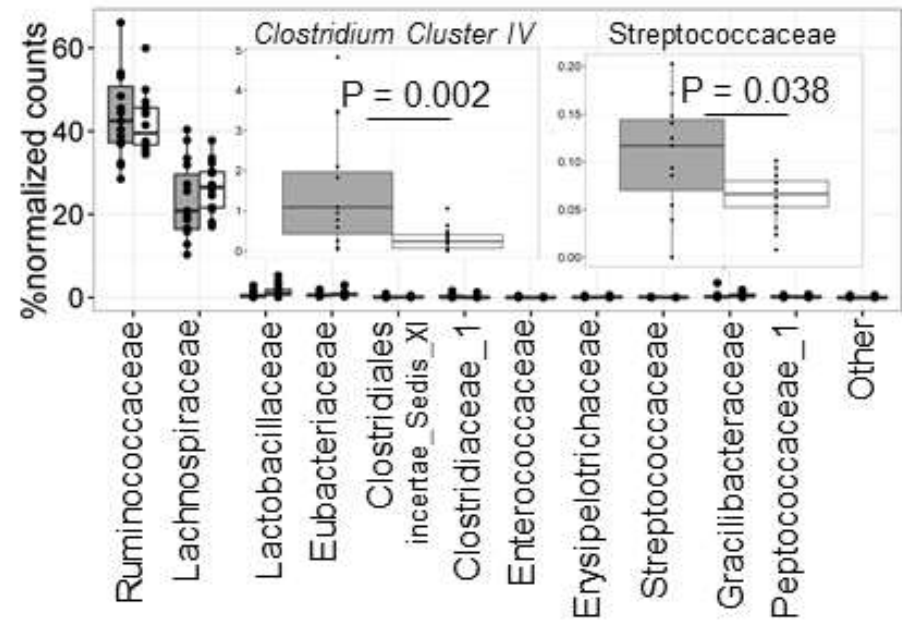

C

D

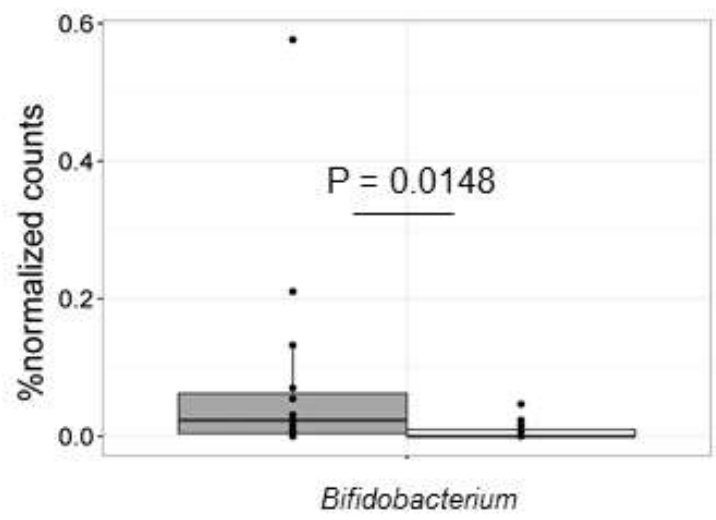

This article is protected by copyright. All rights reserved.

Comment citer ce document 